\section{Factors Affecting Career Choice of Business Students in the Senior High Schools: A Study of Selected Schools in the Cape Coast Metropolis}

\author{
John Archison Duku \\ Xi'an Jiaotong University, School of Management, People's Republic of China \\ archisonjohn@gmail.com

\section{Leticia Bosu} \\ University of Cape Coast, Department of Business and Social Sciences \\ Education, Ghana \\ leticia.bosu@ucc.edu.gh

\section{Dominic Ekow Ansah} \\ University of Cape Coast, Department of Business and Social Sciences Edu- \\ cation, Ghana \\ dominicansah1991@gmail.com
}

\section{Abigail Achiaa Agyapong}

University of Cape Coast, Department of Business and Social Sciences

Education, Ghana

eksraw5@gmail.com

\section{Abigail Afia Bafowaah}

University of Cape Coast, Department of Business and Social Sciences Education, Ghana

archisond@yahoo.com

\section{Ebenezer Kobina Drokow}

University of Cape Coast, School of Business, Ghana

edrokow77@gmail.com

\section{Francisca Arboh}

Hebei University of Technology, School of Economics and Management, People's Republic of China

arboh20@gmail.com

\begin{abstract}
Factors affecting business students' choice of career in accounting and factors affecting business students' inability to choose a career in accounting remains unclear. We used SPSS to analyze data collected from four randomly selected senior high schools in the central region of Ghana through questionnaires. This paper investigated the influences of job opportunities, personal interest, family influence, social status, peer influence, salary expectation, weakness in mathematics, time it takes to become an accountant, and stress involved in the accounting career. The paper then revealed the effects of these in-
\end{abstract}

ORIGINAL SCIENTIFIC PAPER

RECEIVED: JANUARY 2020

REVISED: FEBRUARY 2021

ACCEPTED: FEBRUARY 2021

DOI: 10.2478/ngoe-2021-0006

UDK: 378:005.523

JEL: D81, D91, 125

Citation: Archison Duku, J., Bosu, L., Ekow Ansah, D., Achiaa Agyapong, A., Afia Bafowaah, A., Kobina Drokow, E., \& Arboh, F. (2021). Factors Affecting Career Choice of Business Students in the Senior High Schools: A Study of Selected Schools in the Cape Coast Metropolis. Naše gospodarstvo/Our Economy, 67(1), 61-70. DOI: 10.2478/ ngoe-2021-0006

\section{NG OE}

NAŠE GOSPODARSTVO OUR ECONOMY

Vol.67 No.1 2021

pp. $61-70$ 
fluencing factors. Though other factors were found to have substantial effects, the results clearly shows that high salary expectation and job opportunities are the most influential factors that influences a business student's choice to choose or not to choose a career in accounting. These results could be used as a reference for educational reforms and career counselling.

Keywords: business students, career choice, influential factors

\section{Introduction}

In recent years, the decline in quantity and quality of student enrollments in accounting has caused much alarm among academics, professionals, and professional bodies. This has led researchers to investigate the reasons regarding career choice in the accounting field. Mauldin et al. (2000, p.142) state that "the primary objective of accounting programs is to produce a sufficient number of graduates who possess substantial accounting knowledge, with the strong communication and analytical capabilities demanded by employers". To meet the demands of employers, accounting programs must graduate the best and brightest students with high aptitudes. When there is a continuous decrease in the quantity and quality of graduates in the accounting field, it may mean the education system is not able to meet the demands of the job market. Many factors affect career choices of high school students. Identifying these factors would give parents, educators, and industry an idea as to where students place most of their trust in the career selection process. It would also allow students to examine processes they use for career selection.

Career choice is one of many important decisions students will make in determining future plans. This decision will impact them throughout their lives because, "the essence of who the student is will revolve around what the student wants to do with their life-long work" (Brochert, 2002). Every student carries the unique history of their past and this determines how they view the world and the career opportunities that are available to them in their chosen field of study.

Several studies show that new college students all over the world usually consider a wide variety of factors influencing their career choice decision (Aldrich et al., 2020; Achim, Badrolhisam, \& Zulkipli, 2019). Arghya and co-authors (2020) revealed that convenience, family background, societal status, family income and parental pressure were the (main) factors responsible for career choices among Indian students. In most cases, choice of careers, subjects, and courses of study as well as the subsequent career paths are a nightmare for prospective undergraduate students (Issa \& Nwalo, 2008). This is because most students do not have enough knowledge and information to make the right career choice. Most often, choosing the right subject combination leading to the right profession can make the difference between enjoying and detesting the career in future. Everyone undergoing the process of making a career choice is influenced by such factors as the context in which they live, their personal aptitudes, and educational attainment (Watson et al., 2010).

In 2019, the American Institute of Certified Public Accountants (AICPA) reported that the number of accounting graduates trended downward in the 2017-18 academic year, with decreases of $4 \%$ at both the bachelor's and master's levels. In 2018, female accounting graduates outnumbered male graduates at the master's level. Racial/ethnic diversity has increased in accounting graduates, with a seven (7) percentage point increase in Hispanic or Latino accounting graduates.

Ghana as a developing country, experiences development at a much slower pace compared to developed countries. However, the most important factor to effect national development is human resources. Development of a nation is largely dependent on this singular factor which is the greatest resource any country or nation can have. This resource, if properly harnessed, can catapult a nation to a realm of immense development and growth. Hence, the issue of career choice cannot be ignored and must be effectively managed.

\section{Literature Review}

\section{Concept of choice}

Choice is the outcome of a process which involves assessment and judgment; that is, the evaluation of different options and deciding about which option to choose. For these processes to take place and a choice to be made, there needs to be two or more alternatives from which to choose. In ad- 
dition, these alternatives should have some positive value; in this sense a 'choice' between something which is desired and something which is not desired is not a true choice. The processes entailed in choice all involve cognition, and psychological theories concentrate on explaining how people make choices, in particular the cognitive processes that underlie choice. Empirical research on how people make decisions and choices covers a range of different people in different situations with different levels of cognitive skills. The role of cognitive ability has repeatedly been shown to explain age differences in decision quality and strategy use (Jin, Ji, \& Peng, 2019). These cognitive abilities and their limitations are also influential in constraining choices so that choice making varies from what may be ideal and logical. The way people can and do make decisions varies considerably. Much earlier research has focused on the way we are observed to make decisions and the way in which we should theoretically make decisions, and as a result, the range and diverseness of theory is vast.

\section{Review of empirical literature}

Obiamaka and co-authors (2015) conducted a similar study in Nigeria. They used questionnaires to collect their data, and they used SPSS version 17 to analyze through factor analysis and the t-test. The outcome of their study was that it is difficult for students to choose between pursuing an accounting career in the industry and in academics. This study depicts one factor to be considered in our study; that accounting careers in the industries provide better remuneration. Hezlina and Abdul (2015) also discovered through data collected from Malaysian senior high school students that; parents, especially mothers, have a greater influence over the career choice of their children than the children's peers. However, they also found out that the educational background of parents does not have much influence on the career choice of their children. In 2016, a further study conducted by Haslinah and co-authors in the University of Putra Malaysia also revealed that there were two categories of factors that influence career decisions based on researcher judgement: internal and external factors. The internal factors were identified as interest in the subject, self- perception, the relationship with family, friends, and lecturers. The external factors stated by respondents in the study were educational attainment, salary, experiences from practical training, school and university's entry system and gender gap.

In 2016 Josephine Nyamwange of Masai Mara University, also conducted a similar study in universities in Kenya. The study concluded that student's interest is significant in determining career choice decisions for an individual's career. Another researcher from Zimbabwe, Jeofrey Mtemeri, through his research work in 2017 discovered that family (especially parents), schools, and peers have significant influences on the career choice of students. Research conducted by Kazi and Akhlaq in 2017 also showed the parents' influence as most significant, followed by influence from peers, gender, print media, financial reasons, interest and then others.

In 2020 however, a study conducted by Aldrich and co-authors revealed similar factors. Data collected in this study was analyzed with mean, frequency, and chi-square. The researchers also found that the financial status of students in school affects their personal decisions, but not parental or peer influence. Lastly, Arghya and co-authors (2020), with the use of thematic-based analysis of interviews, conducted in their study of 33 Indian students, discovered that convenience, family background, societal status, family income, and parental pressure were the factors that were responsible for certain career choices of students in India.

All the above works of research brought out the factors that influence students' decision to choose careers. But none of the studies actually categorize the factors into the ones that influences them to choose and the ones that influences them not to choose. Hence, our study will seek to categorize the factors into such categories and find the most influential ones in each respective category.

\section{Methodology}

The design for the study was a descriptive survey. The descriptive survey provides opportunities for researchers to gain valuable insight into the existing state of a phenomenon. The target population for the study consisted of all business students in senior high schools within the Cape Coast Metropolis in the Central Region of Ghana. The total number of business students in the selected schools was 1,320. The accessible population was 440 students. However, in accordance with the formula for determining sample size from a given population given by Krejcie and Morgan (1970), a sample size of 205 students was selected for the study. Out of the total sample, 51 students from each of the first three schools participated in the study, and 52 students from the last school also participated in the study. The respondents were selected through the simple random sampling technique. This sampling technique accords each member of the population an equitable chance of being selected. It suffices to say that the sampling technique was appropriate due to the similitude of the study's population in terms of their characteristics. Also, it will enable us to arrive at an elaborated view on students regarding the study. The simple random technique was used in the research because it ensures that the selection of respondents is free from human bias, and it also gives each member of the group a fair chance of being selected. 


\section{Research questions}

In relation to the research objectives and reviewed literature, the following questions were formulated to guide the study:

1. What are the factors that affect business students' choice of careers in accounting?

2. What are the factors that affect business students' inability to choose careers in accounting?

3. What is the most influential factor that affects business students' choice of careers in the accounting field?

4. What is the most influential factor that affects business students' inability to choose careers in the accounting field?

\section{Research instrument}

Despite the availability of several research instruments, a questionnaire was used in the collection of data from the respondents. The decision to use this instrument stems from the consideration that it is the best method by which reliable responses can be elicited in the study of this kind. The questionnaire was divided into five (5) sections, consisting of 27 items. Section A of the questionnaire sought to gather information from the background of the respondents. These included factors such as gender and age of the respondents. Sections B and C, however, elicited information on the factors affecting the respondents' choice and inability to choose a career in the accounting field, respectively. Sections D and E also required respondents to rate the top three factors that influence their choice or inability to choose a career in accounting, in order of the level of influence.

\section{Data collection and analysis}

Before administering the instrument, we visited the participating schools with a letter of introduction from the Head of Department, Department of Arts, and Social Sciences Education (DASSE), University of Cape Coast. The questionnaires were administered personally. Respondents were briefed as to what the study is about to get their needed attention, support, and co-operation. We had a 100\% rate of return on the questionnaires.

The returned questionnaires were categorized and coded based on the objectives of the study. The responses were therefore transferred onto a spreadsheet, specifically statistical package for social science research (SPSS) version 17 for analysis. Descriptive statistics and the binary logistic regression analysis were finally used to analyze the data.

\section{Results and Discussion}

Research question 1: What are the factors that affect business students' choice of career in accounting?

Section B of the questionnaire sought to gather information about the factors influencing Business students' choice of career in accounting. The results are shown in Table 1.

Table 1. Factors influencing business students' choice of career in accounting

\begin{tabular}{lcccccc}
\hline & \multicolumn{2}{c}{ Agree } & \multicolumn{2}{c}{ Disagree } & \multicolumn{2}{c}{ Total } \\
Factors & No. & $\%$ & No. & $\%$ & No. & $\%$ \\
\hline $\begin{array}{l}\text { Good job } \\
\text { opportunities }\end{array}$ & 116 & 84.1 & 22 & 15.9 & 138 & 100 \\
$\begin{array}{l}\text { Personal } \\
\text { interest }\end{array}$ & 99 & 71.7 & 39 & 28.3 & 138 & 100 \\
$\begin{array}{l}\text { Family } \\
\text { influence }\end{array}$ & 41 & 29.7 & 97 & 70.3 & 138 & 100 \\
$\begin{array}{l}\text { Peer influence } \\
\begin{array}{l}\text { High salary } \\
\text { expectation }\end{array}\end{array}$ & 116 & 11.7 & 121 & 88.3 & 137 & 100 \\
\hline
\end{tabular}

From Table 1, it could be observed that 116 (84.1\%) out of 138 respondents agreed that the availability of a good job opportunity has a great bearing on their decision to pursue a career in accounting. However, the remaining 22 respondents, representing $15.9 \%$, disagreed with the assertion that the availability of good job opportunities has an influence in their choice to undertake a career in accounting. This implies that the availability of good job opportunities in accounting plays an integral role in a respondents' decision to take a career in accounting. The finding concurs with the findings of Nelson, Vendrzyk, Quinn and Allen (2002), who identified changing availability of jobs in accounting as one of the three variables that informs students to take accounting subjects as their major and accountancy as a career aspiration.

Again, the degree of monetary advantage that a particular occupation offers its professionals goes a long way in determining the interest or disinterest of people towards such an occupation. The more the financial benefits associated with a particular career, the greater the inclination of people towards that field of occupation. The study therefore sought to find out how high salary influences students' 
choice of an accounting career. Results from Table 1 shows that out of 138 respondents, 113, representing $81.9 \%$ of the respondents, clearly admitted that their desire to pursue an accounting career is due to the high earnings associated with careers in accounting. However, the remaining 25 respondents, constituting 18.1\%, disagreed with the assertion that the influence of a high salary played a role in their decision to take a career in accounting. Thus, results from Table 4 portray that respondents' choice of careers in accounting is significantly associated with high salary expectations.

Also, the interest of students cannot be overlooked when it comes to decision on which career to pursue. In this respect, a poignant attempt was made to find out from students if their personal interest has an impact on their decision to pursue a career in accounting. Results in Table 1 revealed that out of a total of 138 respondents, a profound number of the respondents 99 (71.7\%), agreed that their quest to offer a career in accounting is influenced by personal interest. The remaining 39 (28.3\%) respondents disagreed that their choice of accounting career is influenced by personal interest. This therefore implies that most respondents choose careers after carefully considering their personal interest in the course. This supports the findings of Aldrich and co-authors (2020), who found that self-choice influences students' decisions.

Additionally, the role of the family in career selection has been viewed as domineering to a degree that violates the principle of self-volition. In this regard, the study sought to find out the role of family influence on students' career aspirations. As shown in Table 1, only 41(29.7\%) of the students agreed that their intent to choose accounting as their career prospect was influenced by their respective families. This is an indication that family pressure has a narrow influence on a business student's choice of a career in accounting. However, a significant number of the respondents 97 (70.3\%) did not agree with the claim that family influence is a major factor behind their quest to pursue a career in accounting. The implication of this is that the role of family influence is quite insignificant when it comes to career selection in accounting among the respondents.

Furthermore, the influence of peers in students' decision-making process cannot be underestimated. This is because most students are more likely to turn to their peers as a point of reference when it comes to a decision on which career to pursue. The results in Table 1 indicated that a small proportion 16 (11.7\%) of the respondents admitted that there is an element of peer influence on their choice of accounting as a career option. Conversely, a larger proportion $121(88.3 \%)$ of the respondents disagreed that it is peer influence that coerced them to pursue an accounting career. Thus, the findings presented in Table 1 depict peer influ- ence as playing an insignificant role in the respondents' choice of an accounting career.

Research question 2: What are the factors that affect business students' inability to choose a career in accounting?

On the other hand, section $\mathrm{C}$ of the questionnaire also sought to elicit information about the factors that affect

Table 2. Factors affecting business students' inability to choose a career in accounting

\begin{tabular}{lcccccc} 
& \multicolumn{2}{c}{ Agree } & \multicolumn{2}{c}{ Disagree } & \multicolumn{2}{c}{ Total } \\
Factors & No. & $\%$ & No. & $\%$ & No. & $\%$ \\
\hline $\begin{array}{l}\text { Better job } \\
\text { opportunities } \\
\text { in other fields }\end{array}$ & 49 & 73.1 & 18 & 26.9 & 67 & 100 \\
$\begin{array}{l}\text { Family } \\
\text { influence }\end{array}$ & 12 & 17.9 & 55 & 82.1 & 67 & 100 \\
$\begin{array}{l}\text { Higher salary } \\
\text { expectation in } \\
\text { other careers }\end{array}$ & 43 & 64.2 & 24 & 35.8 & 67 & 100 \\
$\begin{array}{l}\text { Stress } \\
\text { involved in }\end{array}$ & 38 & 56.7 & 29 & 43.3 & 67 & 100 \\
$\begin{array}{l}\text { accounting } \\
\text { careers }\end{array}$ & & & & & & \\
$\begin{array}{l}\text { Length of } \\
\text { time taken to } \\
\text { become an } \\
\text { accountant }\end{array}$ & 28 & 41.8 & 39 & 58.2 & 67 & 100 \\
$\begin{array}{l}\text { Weakness in } \\
\text { mathematics }\end{array}$ & 16 & 23.9 & 51 & 76.1 & 67 & 100 \\
\hline
\end{tabular}

business students' inability to choose a career in accounting. Results are shown in Table 2.

For Table 2, the 67 respondents who stated that they do not want to take a career in accounting were further asked to cite reasons for their dislike for accounting careers. 49 representing 73.1\%of these students cited better job opportunities that other careers offer as the reason behind their decision. However, the remaining 18 respondents, constituting 26.9\%, did not accept the statement that better job opportunities offered by other career influenced their decision to shift away from an accounting career. This finding implies that better job opportunities provided by other disciplines have the tendency to sway the respondents from pursuing careers in accounting.

Regarding the expectation of earning high salaries in other careers, results from Table 2 showed that 43 (64.2\%) of 
the respondents admitted that their decision to engage in other careers and not accounting is motivated by the higher salary earnings associated with other career professions. This could stem from the fact that respondents might have observed people in other professions excelling in life more than some people in accounting jobs. Interestingly, 24 of the respondents, making up 35.8\%, did not agree that high salaries connected with other careers are the reason for not taking up an accounting career. Findings from Table 5 imply that higher salary expectations associated with other job opportunities are a contributing factor for respondents' inability to take a career in accounting. This is in line with Jeofrey Mtemeri's research finding through his research work in 2017. He found out that financial reasons have a significant influence on students' decision to choose a particular career.

Also, family influence is said to have necessitated the change of business students from accounting to other job opportunities. However, from Table 2, a small number 12 (17.9\%) of the respondents agreed that their decision to move from accounting career was indeed influenced by family pressure. On the contrary, a great proportion 55 (82.1\%) of the respondents disagreed with the role of family influence on their decision to venture into other careers other than accounting. Thus, from Table 5, it is worthwhile to note that family influence has little to do with the respondents' decision to choose other career fields ahead of accounting. The finding of the study contradicts the findings of Constantinou, Michailidis and Kyriakidou (2011). Constantinou, Michailidis and Kyriakidou found that there is a significant association between family and students' preference for a particular course of study, and that parents are more influential in students' decision compared to other factors.

Stress embedded in certain categories of career opportunities has been found to affect the decision to choose or no to choose certain occupations. Results presented in Table 2 indicate that out of the 67 respondents, 38 (56.7\%) of the respondents attributed their inability to take a career in accounting to perceived stress involved in the accounting career options. However, 29 representing $43.3 \%$ of respondents, disagreed with the statement that stress associated with accounting career options could have shifted their choice of career in accounting to other fields. This finding implies that stress associated with accounting inclined occupations diminishes the spirit of most respondents, hence, their preference for careers in other disciplines.

Again, the strength and weakness of individual students in a particular subject area is said to be a good recipe for cogent decision making as far as career aspiration is concerned. Results from Table 2 showed that out of 67 re- spondents, a small number 16 (23.9\%) of the respondents agreed that their inability to opt for a career in accounting is because of their weakness in mathematics. Indeed, accounting is mathematics oriented, and any student who has a mathematics phobia may not desire to use it as a career option. Despite this fear expressed by these 16 students, a great proportion 51 (76.1\%) of students did not ascribe their inability to select career in accounting as their career prospect to the mathematical nature of accounting. This finding implies that most respondents do not consider the mathematical nature of accounting as the main reason for their inability to choose a career in accounting.

Research questions 3 \& 4: What is the most influential factor that influences business students to choose a career in accounting or not?

The model for the study was tested before the analysis for the third and fourth research questions were made. The chisquare test was used in the analysis of the top three most influential factors in each scenario (Table 3).

Table 3. Omnibus test

\begin{tabular}{lccc} 
& Chi-square value & df & Sig. \\
\hline Likelihood Ratio & 22.080 & 6 & 0.000 \\
Pearson & 22.052 & 6 & 0.000 \\
\hline
\end{tabular}

The results of the test show that our model containing the set of predictors identified in the study represents a significant (i.e., $\mathrm{p}<0.001$ ) improvement on fit when compared to an unconditional model with no predictors. The results of the two chi-square tests also gave us quite similar values, which indicates that our predictors are correlated.

A further test of our model revealed that $11.2 \%$ to $56.9 \%$ of the variance in our dependent variable is explained by our dependent variables. This indicates that our independent variables in the model are good predictors of the dependent variable. The results are shown in Table 4.

Table 4. Model summary

\begin{tabular}{lcc}
\hline Step & Cox \& Snell R square & Nagelkerke R square \\
\hline 1 & 0.112 & 0.569 \\
\hline
\end{tabular}

Many factors come in to play when it comes to factors that influence business students to take career in accounting. However, these factors have different degrees of influence on individual student's decision-making process. Hence, sections $\mathrm{D}$ and $\mathrm{E}$ of the questionnaire sought to ascertain 
the most influential factor that influences a students’ decision to take up a career in accounting, as well as the most influential factor that influences a student to do otherwise. Binary logistic regression analysis in SPSS was used to analyze the data and the results are presented in Table 5.

Table 5. The most influential factors that influences business students to choose a career in accounting or other fields

\begin{tabular}{lccc}
\hline Predictor & B & Sig. & Exp (B) \\
\hline $\begin{array}{l}\text { Good job opportunities } \\
\text { High salary expectation }\end{array}$ & 0.798 & 0.000 & 1.721 \\
in accounting jobs & 1.021 & 0.000 & 2.642 \\
$\begin{array}{l}\text { Personal interest } \\
\begin{array}{l}\text { Better job opportunities in } \\
\text { other fields }\end{array}\end{array}$ & 0.661 & 0.005 & 1.122 \\
$\begin{array}{l}\text { Stress involved in } \\
\text { accounting jobs }\end{array}$ & -0.698 & 0.000 & 2.374 \\
$\begin{array}{l}\text { High salary expectation in } \\
\text { other fields }\end{array}$ & -0.822 & 0.000 & 1.692 \\
\hline
\end{tabular}

Source: Field data, 2018

To determine the most influential factors that influence business students to choose a career in accounting, respondents (who opted for careers in accounting) were made to rank the three most influential factors that influence their decision in the order of the degree of influence.

From Table 5 above, it can be seen that, holding all the other factors constant, with a single increase in the expectation of high salaries in the accounting field, a business student is 2.642 times more likely to choose a career in the accounting field than other fields. This clearly shows that most of the respondents believe that their expectation of earning high salaries in accounting careers is the most influential factor in choosing a career in accounting. Good job opportunities in the accounting field are the second most influential factor, while personal interest is the least influential among the three factors that had a positive effect on students' decision (with odds ratios of 1.721 and 1.122 respectively). The positive regression coefficients (B) indicate that there exists a positive relationship between the three factors (high salary expectation, good job opportunities and personal interest) and the choice of a career in accounting. Thus, the more business students consider these factors as important in their decision making, the more likely they are to choose careers in the field of accounting. This finding is in line with Nur'ain and co-authors (2019), who also identified salary and other benefits as influential factors in career decision making.

Results from Table 5 also shows that the most influential factor responsible for business students' decision not to pur- sue careers in accounting is their perception of obtaining better job opportunities in other fields. This is because it has the highest odds ratio among the predictors with negative beta values as shown in Table 5 above. Thus, when all other factors are held constant, with a single increase in the expectation of better job opportunities in other fields, a business student is 2.374 times more likely to choose a career outside the accounting field. With an odds ratio of 1.692, high salary expectation in jobs outside the field of accounting is the second most influential factor that influences students' decision to pursue a career in other non-accounting fields. Stress involved in accounting careers was identified as the least influential among the three influential factors with a negative effect (having an odds ratio of 0.785 ). The negative regression coefficients (B) show that there is a negative relationship between these factors and the students' decision to opt for a career in the field of accounting. Thus, the higher the influence of these factors, the less likely it is that the student might opt for a career in the accounting field.

\section{Conclusion}

With respect to factors influencing business students' choices of career in accounting, the study revealed five factors, namely, good job opportunities, personal interest, social status, peer influence and high salary expectations. With respect to factors affecting students' inability to choose a career in accounting, the study revealed six factors, namely, better job opportunities in other fields, high salary expectations in careers in other fields, family influence, weakness in mathematics, length of time taken to become an accountant, and the stress involved in accounting careers. Regarding the most influential factor that affects business students' choice of career in accounting, the study revealed that most respondents agreed that high salary expectation was the most influential factor. On the issue of most influential factor that affects business students' inability to choose a career in accounting, the study revealed that most respondents agreed that better job opportunities in other fields was the main factor.

Based on the objectives of the study and the corresponding findings presented above, the following conclusion could be drawn: There is sufficient evidence from the study to conclude that there is a positive relationship between students' decision to pursue accounting careers and factors such as availability of good job opportunities in accounting, personal interest, social status, and high salaries. Thus, when all these factors are prevalent, students would be enthused to pursue a career in accounting. However, a high salary expectation is the most influential factor that is likely to influence the decision of most business students 
as far as career choice is concerned. From the study, it is imperative to conclude that factors such as better job opportunities, higher salary earning associated with other careers, and stress inherent in accounting related jobs have a greater tendency to influence business students not to pursue a career in accounting. However, the most influential factor that is likely to influence business students to pursue careers in other fields other than accounting is the better job opportunities that other fields offer.

\section{Recommendation}

Based on the findings and conclusions drawn, the following recommendations are made: Heads of second cycle institutions in collaboration with Ministry of Education should organize sensitization workshops to enlighten all students on the need and importance of accounting as a subject of study. This will tend to broaden the understanding of students, and hence motivate them to pursue accounting related careers. For students to make the right career choice, the family (parents) should be encouraged not to force their children into careers. With parental guidance and support, children can make the right career choice. Teachers, like parents, work very closely with learners in schools and they know the abilities of their students in various subjects. Therefore, teachers should guide their students in their career choice and aspirations in line with their abilities in various subjects. Heads of schools should ensure that their schools provide career guidance to learners during their high school studies. The career guidance programs guide learners in making their career choices and aspirations before entering university.

\section{Areas for further studies}

Future research on the same topic should be extended to other schools in other regions in the country to enable generalization. This study only focused on the schools in Cape Coast Metropolis, hence the need to extend this study to other parts of the country. In addition, future research should be extended to include first- and second-year business students also. This is because this study only focused on final year business students.

\section{References}

Achim, N., Badrolhisam, N. I., \& Zulkipli, N. (2019). Employee career decision making: the influence of salary and benefits, work environment and job security. Journal of Academia, 7(1), 41-50.

Albrecht, W. S., \& Sack, R. J., (2000). Accounting Education: Changing the Course through a Perilous Future. Accounting Education Series, 16, American Accounting Association, Saratosa.

Bandura, A., Barbaranelli, C., Caprara G.V., \& Pastorelli, C. (2001). Self-efficacy beliefs as shapers of children's aspirations and career trajectories. Child Development. Rome: Italy, MCSER Publishing. https://doi.org/10.1111/1467-8624.00273

Borchert, M. (2002). Career choice factors of high school students. Retrieved from http://www2.uwstout.edu/content/lib/thesis/2002/2002borchertm.pdf

Constantinou, A., \& Michailidis M.P. (2011). Factors that influence students' choice for undergraduate studies. Leeds Metropolitan University: UK.

Dowson, M., \& Mclnerney, D. M. (2001). Emotions and classroom talk: Toward a model of the role of affect in students' experiences of classroom discussions. Journal of Educational Psychology, 10(2), 29-34.

Geiger, M.A., \& Ogilby, S.M. (2000). The first course in accounting: student's perceptions and their effect on the decision to major in accounting. Journal of Accounting Education, 18, 63-78. https://doi.org/10.1016/S0748-5751(00)00011-7

Glass, J.C. \& Oakley, B. (2003). Attrition and retention among accounting majors in community colleges: problems and possible remediation. Community College Journal of Research and Practice, 27, 679-698.

Hairston J.E. (2000). How parents influence African American students' decision to prepare for vocational teaching career. Journal of career and Technical Education, 16(2), 1-15. https://doi.org/10.21061/jcte.v16i2.547

Hardin, J.R., D.O’Bryan, \& J.J. Quirin. (2000). Accounting versus engineering, law, and medicine: Perceptions of influential high school teachers. Advances in Accounting, JAI. 17, 205-220.

Haslinah M., \& Mariati, M. S., \& Mohd Sufri, M. N. (2016). Factors influencing career choice of accounting students in University Putra Malaysia: Qualitative pilot study. Journal of Advanced Research in Social and Behavioural Sciences, 1, 25-34.

Hastie, R. \& Dawes, R.J. (2001) Rational Choice in an Uncertain World: The psychology of judgment and decision making. Thousand Oaks, CA: Sage.

Hezlina M. H., \& Abdul M. E. (2015). Parental and Peer Influences upon Accounting as a Subject and Accountancy as a Career.Journal of Economics, Business and Management, 3(2), 252-256.

Issa, A.O., \& Nwalo, K.I.N. (2008). Factors Affecting the Career Choice of Undergraduates in Nigerian Library and Information Science Schools. African Journal of Library, Archives and Information Science, 10, 47-51.

Krejcie, R.V., \& Morgan, D.W. (1970). Determining Sample Size for Research Activities. Educational and Psychological Measurement, 30, 607-610. https://doi.org/10.1177/001316447003000308 
Lyons, T., \& Quinn, F. (2010). Understanding the declines in senior high school science enrolments. National Centre of Science, ICT and Mathematics Education for Rural and Regional Australia (SiMERR Australia), University of New England.

Macgregor, K. (2007). Student Dropout Rates Alarming in SA Universities. Johannesburg: FEP Publishers.

Mauldin, S., Crain, J.L. \& Mounce, P.H. (2000). The accounting principles instructor's influence on student's decision to major in accounting. Journal of Education for Business, 75(3), 142-148. https://doi.org/10.1080/08832320009599005

McMahon, M., \& Watson, M. (2005). Occupational information: What children want to know? Journal of Career Development, 10(2), 69-82.

Mtemeri, J. (2017). Factors Influencing the Choice of Career Pathways among High School Students in Midlands Province, Zimbabwe.

Nelson, I. T., Vendrzyk, V.P., Quirin, J. J., \& Allen, R. D. (2002). No, the Sky Is Not Falling: Evidence of Accounting Student Characteristics at FSA Schools, 1995-2000. Issues in Accounting Education, 17 (3), 269-268. https://doi.org/10.2308/iace.2002.17.3.269

Nyamwange, J. (2016). Influence of Student's Interest on Career Choice among First Year University Students in Public and Private Universities in Kisii County, Kenya. Journal of Education and Practice, 7(4), 96-102.

O’Leary, Z. (2004). Essential Guide to Doing Research. California: SAGE Publications Ltd.

Obiamaka, N. et al. (2015). Proceedings of ICERI2015 Conference 16th-18th November 2015, Seville, Spain.

Odia, J.O., \& Ogiedu, K.O. (2013). Factors Affecting the Study of Accounting in Nigerian Universities. Rome: Italy, MCSER Publishing. https://doi.org/10.5901/jesr.2013.v4n3p89

Over, D. (2004) Rationality and the normative/descriptive distinction. In D.J. Koehler and N. Harvey (eds), Blackwell Handbook of Judgment and Decision Making. Oxford: Blackwell.

Rask, K. N., \& Bailey, E. M. (2002). Are faculty role models? Evidence from major choice in an undergraduate institution. Journal of Economic Education, 5(2), 35-42 https://doi.org/10.1080/00220480209596461

Ray, A., Bala, P., Dasgupta, S., \& Srivastava, A. (2020). Understanding the factors influencing career choices in India: from the students' perspectives. International Journal of Indian Culture and Business Management, 20(2), 175-193.

Smith, G. (2005). Reversing the decreasing trend of students majoring in accounting. Managerial Auditing Journal, 20(9), $936-944$. https://doi.org/10.1108/02686900510625280

Tan, L. M., \& Laswad, F. (2006), Students' beliefs, attitudes, and intentions to major in Accounting. Accounting Education: an international journal, 15(2), 167-187. https://doi.org/10.1080/09639280600787194

Taylor Research and Consulting Group, Inc. (2000, July). AICPA Student and Academic Research Study-Final Quantitative Report.

Watson, M., McMahon, M., Foxcroft, C., \& Els, C. (2010). Occupational Aspirations of Low Socio-Economic Black South African children. Journal of Career Development, 15(2), 176-180. https://doi.org/10.1177/0894845309359351

Yayla, H.E., \& Cengiz, E. (2005). Factors influencing major selection by college of business students. The International Journal of Career Management, 6(3), 20-26.

\section{Dejavniki, ki vplivajo na izbiro kariere pri dijakih srednjih poslovnih šol: študija izbranih šol v metropoli Cape Coast}

\section{Izvleček}

Dejavniki, ki vplivajo na to, da dijaki srednjih poslovnih šol izberejo kariero v računovodstvu in dejavniki, ki vplivajo na to, da se dijaki srednjih poslovnih šol ne odločijo za kariero v računovodstvu, ostajajo nejasni.Z uporabo programa SPSS smo analizirali podatke s štirih naključno izbranih srednjih šol v osrednji regiji Gane, pridobljene s pomočjo vprašalnikov. Ta prispevek raziskuje vplive zaposlitvenih možnosti, osebnih zanimanj, družine, družbenega statusa, vrstnikov, pričakovanj glede plače, šibkega znanja matematike, trajanja usposabljanja za računovodjo in stresa, ki je prisoten v računovodskem poklicu ter razkriva učinke omenjenih vplivnih dejavnikov. Čeprav je bilo ugotovljeno, da imajo tudi drugi dejavniki bistven vpliv, rezultati jasno kažejo, da dejavnika ‘visoka pričakovanja glede plače’ in ‘zaposlitvene možnosti’ najbolj vplivata na to, da se dijaki srednjih poslovnih šol odločijo za kariero v računovodstvu ali ne. Ti rezultati bi lahko služili kot referenca za reforme izobraževanja in karierno svetovanje.

Ključne besede: dijaki srednjih poslovnih šol, izbira kariere, vplivni dejavniki 